\title{
Radiological characterization of a German pressurized water reactor based on a highly resolved method for activity analysis and dose rate calculation
}

\author{
Markus Nolden, Agnes Scaramus, Rahim Nabbi, Frank Charlier, and Klaus Fischer-Appelt \\ Chair of Repository Safety (ELS), RWTH Aachen University, Aachen, 52062, Germany \\ Correspondence: Markus Nolden (nolden@els.rwth-aachen.de) and \\ Agnes Scaramus (scaramus@els.rwth-aachen.de)
}

Published: 10 November 2021

\begin{abstract}
The amendment to the atomic act in 2011 results to phase out nuclear energy in Germany until the end of 2022. Subsequently, the licensee of the nuclear power plant is responsible for decommissioning and dismantling. During operation, activation of structures near the core of the reactor occur which govern the amount of radioactive waste, the dose rate distribution and dismantling strategies. Thus, a detailed radiological characterization of in-core and out-core structures is required to optimize decommissioning processes regarding the quantification and minimization of radioactive waste, radiation protection and reducing radiation exposure. These objectives are achieved using an innovative and efficient method developed and applied at the Chair of Repository Safety (Lehrstuhl für Endlagersicherheit, ELS) RWTH Aachen University.

Within the framework of the joint project ,Development of a methodology for activity analysis and dose rate estimation", funded by the Federal ministry of Education and Research, approaches the objective to develop a standardized and highly resolved method to calculate time-dependent activity of components and structures near the reactor core based on operating history of the nuclear power plant and neutron fluence distribution. The approach requires the development of a detailed model for Monte-Carlo simulations which provides the basis to neutron fluence, neutron spectra and radiation transport simulations. To calculate the nuclide specific 3Dimensional (3D) activity distribution of the entire facility, a facility-dependent activation cross section library is produced which focuses on recent nuclear databases (ENDF/B-VIII.0). A highly resolved and space-dependent 3D activity distribution of the entire facility is obtained using a modular program package, developed at ELS, including the activation code ORIGEN2. The results are produced in the form of detailed 3D activity maps.

The source terms are generated on the basis of the space-dependent 3D activity distribution using an additional module of the program package. The combination of recent nuclear databases focusing on ENDF/B-VII.1 and complemented by JEFF-3.3 ensures a comprehensive characterisation of source terms. Subsequently, source terms are prepared for 3D radiation transport simulation using the Monte-Carlo method and the computer code MCNP. The simulations are conducted separately for each individual component obtaining the partial contribution of all in-core and out-core structures as well as the dose rate distribution of the entire facility. Similar to the activity calculation, the simulation results are used to generate 3D gamma flux and dose rate maps using the graphic module of the whole program system. On the basis of the radiological characterisation and in view of a high-level radiation protection these maps allow the optimum planning and realisation of the decommissioning and dismantling process of the nuclear power plant.
\end{abstract}

Kurzfassung. Mit der Novellierung des Atomgesetzes im Jahr 2011 wurde der Ausstieg aus der Kernenergie in Deutschland bis Ende 2022 beschlossen. Damit ist der Genehmigungsinhaber jeder Anlage für die Zeit danach für die Stilllegung und den Rückbau des Kernkraftwerkes verantwortlich. Während des Betriebs werden die Bauteile und Strukturen in der Nähe des Reaktorkerns aktiviert, wovon das Volumen und Inventar des radioaktiven Abfalls sowie die Dosisleistungsverteilung und die Rückbaustrategie abhängen. Vor diesem Hintergrund 
ist eine detaillierte radiologische Charakterisierung der Bauteile und Strukturen in der Umgebung des Reaktorkerns notwendig. Damit können für die Rückbauprozesse und Entsorgung die Minimierung des radioaktiven Abfalls sowie die Optimierung des Strahlenschutzes zur Verringerung der Strahlenexposition des Personals erreicht werden. Diese Ziele werden mit Hilfe einer innovativen und effizienten Methode, welche am Lehrstuhl für Endlagersicherheit (ELS) der RWTH Aachen entwickelt und angewendet wurde, realisiert.

Das Verbundprojekte „Entwicklung und Anwendung einer Methode zur Aktivitätsberechnung und Dosisleistungsberechnung“, gefördert vom Bundesministerium für Bildung und Forschung (BMBF), verfolgt das Ziel einer standardisierten und hochaufgelösten Methode zur Berechnung des Aktivitätsinventars und der Dosisleistung von kernnahen Bauteilen und Komponenten basierend auf der Betriebshistorie des Kernkraftwerkes und der Neutronenfluenzverteilung zu entwickeln. Dieses Verfahren erfordert die Entwicklung eines detaillierten Modells für Monte-Carlo Simulationen, welches die Grundlage für Neutronenfluenz-, Neutronenspektrum-, und Strahlentransportsimulationen bildet. Zur Berechnung der nuklidspezifischen 3-dimensionalen (3-D) Aktivitätsverteilung in der gesamten Anlage wird eine anlagenspezifische Aktivierungswirkungsquerschnittsbibliothek erstellt, die auf den aktuellen nuklearen Datenbanken (ENDF/B-VIII.0) basiert. Das modulare Programmsystem, entwickelt am ELS, und der Aktivierungscode ORIGEN2 ermöglicht die Berechnung einer räumlich hochaufgelöste 3D-Aktivitätsverteilung der gesamten Anlage. Die Ergebnisse stehen auch als detaillierte 3DAktivitätsatlas zur Verfügung.

Die Strahlungsquellterme werden auf der Grundlage der raumabhängigen 3D-Aktivitätsverteilung mit Hilfe eines weiteren Moduls des Programmpakets erzeugt. Die Kombination aktueller nuklearen Datenbanken mit dem Hauptbestandteil ENDF/B-VII.1 und der Komplementierung durch JEFF-3.3 gewährleistet eine umfassende und aktuelle Charakterisierung der Strahlungsquellterme. Anschließend werden die Quellterme als Grundlage für 3D-Strahlentransportberechnungen mit dem Monte-Carlo-Code MCNP aufbereitet. Die Simulationen werden für jedes Segment der Bauteile bzw. Komponenten separat und in hohem Detaillierungsgrad durchgeführt, um den individuellen Beitrag der einzelnen In- und Outcore-Strukturen in der integralen Verteilung der Dosisleistung der gesamten Anlage zu erhalten. Ähnlich wie bei der Aktivitätsverteilung stehen die Simulationsergebnisse der Strahlentransportberechnungen (als Ergebnis des Visualisierungsmoduls des Programmsystems) in Form von 3D-Gammafluss- und Dosisleistungsatlanten zur Verfügung. Auf der Grundlage der radiologischen Bewertung ermöglichen diese Atlanten die Optimierung der Planung und Durchführung der Rückbauprozesse und der Strahlenschutzmaßnahmen.

Financial support. The joint project is funded by the Federal Ministry for Education and Research (BMBF) within the framework of research for decommissioning of nuclear facilities under the contract no. 15S9409B. 